\title{
EFFECT OF 12.5\% VIRGIN COCONUT OIL (COCOS NUCIFERA) MOUTHWASH ON PLAQUE INDEX OF FIXED PROSTHETIC DENTURE USERS
}

\author{
LEO SAPUTRA, FARISZA GITA*, RATNA SARI DEWI
}

\author{
Department of Prosthodontics, Faculty of Dentistry, Universitas Indonesia, Jakarta, Indonesia. Email: farisza.gita@yahoo.com
}

Received: 16 September 2017, Received and Accepted: 17 September 2017

ABSTRACT

Objective: To find out the difference in the plaque index scores of FPD users before and after using a $12.5 \%$ VCO mouthwash.

Methods: The plaque index measurement of an abutment tooth was taken on 40 subjects with FPD in both test and control groups. Subjects used a $12.5 \%$ VCO mouthwash or aquades twice a day for 4 days after brushing their teeth. Statistical analysis of the measurement result of the plaque index scores before and after using the coconut oil mouthwash was done using the Wilcoxon test.

Results: There is a statistically significant difference in the plaque index scores of FPD users before and after using the $12.5 \%$ VCO mouthwash with a statistically significant decrease in plaque index scores among restoration margin locations and tooth brushing habits, but not among age and gender groups.

Conclusion: Using a 12.5\% VCO mouthwash may decrease the plaque index of fixed prosthetic denture users.

Keywords: Fixed prosthetic denture, Plaque index, Virgin coconut oil.

(C) 2017 The Authors. Published by Innovare Academic Sciences Pvt Ltd. This is an open access article under the CC BY license (http://creativecommons. org/licenses/by/4. 0/) DOI: http://dx.doi.org/10.22159/ijap.2017.v9s2.11

\section{INTRODUCTION}

Periodontium tissue is the tissue around the teeth consisting of gingiva, connective tissue, teeth-supporting bone, and cementum. Gingivitis is a common periodontal problem found both in patients with healthy teeth and in those with dentures. One of the causes is plaque accumulation, which may happen due to crowding teeth; on dentures, especially fixed prosthetic dentures, it is affected by the location of restoration margins, the roughness of the dentures' surface, and the contour of the fixed prosthetic dentures' (FPD) crown [1]. This study shows that an abutment tooth on a FPD has a bigger plaque index, gingival index, and pocket depth compared to an-abutment tooth [2].

Gingivitis will lessen if the plaque accumulation can be stopped. To prevent or decrease plaque accumulation, plaque cleansing should be done. There are many ways to eliminate plaque, including tooth brushing and using mouthwash [1]. At present, available mouthwashes contain several chemical substances that may cause side effects, such as a change in taste perception, desquamation, and staining [3]. Therefore, in the past decade many antibacterial herbal substances, such as virgin coconut oil (VCO), have been increasingly used as a mouthwash.

VCO is well known and widely used in Indonesia. It can be extracted from fresh coconut flesh and has many benefits; it is cheap and easy to get, colorless and fragrant, and has no side effects when swallowed [3]. VCO contains medium chain fatty acids, such as lauric acid, capric acid, and caprylic acid, which have antibacterial, antivirus, antifungal, and antiprotozoal properties $[3,4]$. A previous study showed that VCO can decrease plaque and gingival indexes significantly, [3] and that $12.5 \%$ VCO mouthwash is effective in decreasing the gingival index in patients using a bridge [5].

Therefore, this writer was interested in finding out whether pure coconut oil used as mouthwash could decrease the plaque index score of FPD users since the use of FPD is one of the precipitating factors of plaque accumulation.

\section{METHODS}

This was a clinical experimental study conducted in February-April 2017 with Ethical Approval No. 7/Ethical Approval/FKGUI/II/2017, with 40 subjects who were randomly divided into two groups: The test group that used the $12.5 \%$ VCO mouthwash and the control group that used aquades. Subjects were patients at the dental teaching hospital, Faculty of Dentistry Universitas Indonesia, with fixed metal porcelain dentures as definitive restoration who consented to participate in the study and fulfilled the defined inclusion criteria. Inclusion criteria were: Having good systemic health, not having diabetes mellitus, not having a sulcus depth of $\geq 5 \mathrm{~mm}$, not consuming antibiotics, not smoking, and not using a fixed orthodontics appliance.

After receiving clearance from the Ethical Committee of Faculty of Dentistry Universitas Indonesia, and informed consent from the subjects, a measurement of initial plaque indexes before using mouthwash was done using a disclosing solution applied on the buccal/ labial and palatal/lingual surfaces of an abutment tooth using cotton buds.

The subjects were instructed to wash their mouth once. Then, a picture of the subject's tooth was taken, and plaque accumulation was observed on both surfaces. A plaque index score was given according to the guide and recorded on the measurement form. A score of 0 was given if there was no plaque; a 1 was given if there were separated spots of plaque on the cervical part of the tooth; a 2 was given if there was a thin (approximately $1 \mathrm{~mm}$ ), continuous layer of plaque on the cervical part of the tooth; a 3 was given if the plaque layer was thicker than $1 \mathrm{~mm}$ and covered less than one-third of the tooth crown; a 4 was given if the plaque cover done to two-thirds of the tooth crown; and a 5 was given if the plaque covered more than two-thirds of the tooth crown. The plaque index of the abutment tooth was the mean of the scores of each surface measured. This plaque index score measurement procedure is in accordance with the Turesky, Gilmore, and Glickman method [6]. 
Afterward, subjects were only allowed to brush their teeth with a toothbrush and toothpaste and use a designated mouthwash for 4 days, starting from the morning after the initial measurement until the morning before the final measurement. The mouthwash was given in a $30 \mathrm{ml}$ bottle, and $15 \mathrm{ml}(1 / 2$ bottle) was used each time to wash the mouth for $30 \mathrm{~s}$; it was then spit out without being rinsed with water afterward. Mouthwash was used twice a day after tooth brushing, in the morning after breakfast and at night before bed. On the $5^{\text {th }}$ day, a final measurement of the plaque index was taken.

Data analysis was performed using the Wilcoxon test to compare the plaque index scores of FPD users before and after using the $12.5 \%$ VCO mouthwash and aquades and also to compare the decrease in the plaque index scores before and after using the $12.5 \%$ VCO mouthwash according to gender, tooth brushing habits, and restoration margin locations. The Kruskal-Wallis test was also done to compare the difference in decrease of the plaque index scores of FPD users before and after using the $12.5 \%$ VCO mouthwash based on age.

\section{RESULTS}

Subjects' characteristics based on age, gender, tooth brushing habits, and location of restoration margin are shown in Table 1.

The normality of plaque index score data before and after using the $12.5 \%$ VCO mouthwash and aquades were tested using the Shapiro-Wilk test. The test showed that the obtained data were distributed abnormally $(p<0.05)$. Therefore, statistical analysis was performed using a nonparametric test (the Wilcoxon test) to compare plaque index scores before and after using the $12.5 \%$ VCO mouthwash and aquades.

Table 2 summarizes a statistically significant difference in plaque indexes before and after using the $12.5 \%$ VCO mouthwash ( $p<0.001)$. Using the $12.5 \%$, VCO mouthwash clearly decreased the plaque indexes of FPD users. Meanwhile, there was no statistically significant difference in plaque indexes before and after using aquades $(\mathrm{p}=0.157)$.

Statistical analysis was also performed using the Mann-Whitney test to determine the difference in decrease of the plaque index scores of FPD users before and after using $12.5 \%$ VCO mouthwash and aquades.

Table 3 summarizes a statistically significant difference between plaque index scores before and after using $12.5 \%$ VCO mouthwash and aquades $(\mathrm{p}<0.001)$. Usage of the $12.5 \%$ VCO mouthwash resulted in a greater decrease of plaque index scores compared to the use of aquades.

Next, statistical analysis was performed using the Kruskal-Wallis test to determine the difference in decrease of the plaque index scores of FPD users before and after using $12.5 \%$ VCO mouthwash between age groups, and using the Mann-Whitney test to determine the difference in decrease of plaque index scores of FPD users before and after using $12.5 \%$ VCO mouthwash according to gender, tooth brushing habits, and restoration margin location groups.

Table 4 summarizes that there was no statistically significant difference in decrease of the plaque index scores of FPD users before and after using $12.5 \%$ VCO mouthwash between age groups ( $\mathrm{p}=0.38$ )

Table 5 summarizes that there was no statistically significant difference in decrease of plaque index scores between gender groups $(p=0.672)$; however, there was a statistically significant difference in decrease of plaque index scores according to the tooth brushing habits $(\mathrm{p}=0.02)$ and restoration margin locations $(\mathrm{p}=0.004)$ of FPD users before and after using $12.5 \%$ VCO mouthwash.

\section{DISCUSSION}

This study was an experimental clinical study which should have used a randomized sampling method [7]. However, randomized sampling
Table 1: Subjects' characteristics based on age, gender, tooth brushing habits, and location of restoration margins

\begin{tabular}{ll}
\hline Variable & Total $\mathbf{n}(\%)$ \\
\hline Test group & $20(100)$ \\
Control group & $20(100)$ \\
Age & \\
Test group (years old) & \\
$18-44$ & $11(55)$ \\
$45-64$ & $7(35)$ \\
$\geq 65$ & $2(10)$ \\
Control group (years old) & \\
18-44 & $9(45)$ \\
$45-64$ & $3(15)$ \\
$\quad \geq 65$ & $8(40)$ \\
Gender & \\
Test group & \\
$\quad$ Male & $5(25)$ \\
Female & $15(75)$ \\
Control group & \\
$\quad$ Male & $11(55)$ \\
Female & $9(45)$ \\
Tooth brushing habit & \\
Test group & \\
Regularly & \\
Irregularly & $14(70)$ \\
Control group & $6(30)$ \\
Regularly & \\
Irregularly & $11(55)$ \\
Restoration margin locations & $9(45)$ \\
Test group & \\
Equigingival & \\
Subgingival & \\
Control group & Equigingival \\
Subgingival & $15(75)$ \\
\hline
\end{tabular}

Table 2: Difference in plaque index scores of FPD users before and after using $\mathbf{1 2 . 5 \%}$ VCO mouthwash and aquades for 4 days

\begin{tabular}{lllll}
\hline Mouthwash & $\mathbf{n}$ & \multicolumn{2}{l}{ Median (minimum-maximum) } & \multirow{2}{*}{$\mathbf{p}$} \\
\cline { 3 - 4 } & & $\begin{array}{l}\text { Plaque index } \\
\text { score before } \\
\text { using mouthwash }\end{array}$ & $\begin{array}{l}\text { Plaque } \\
\text { index score } \\
\text { after using } \\
\text { mouthwash }\end{array}$ & \\
\hline $12.5 \%$ VCO & 20 & $1.5(1-2.5)$ & $0.5(0-1)$ & $<0.001$ \\
Aquades & 20 & $1.5(1-2.5)$ & $1.5(1-2.5)$ & 0.157 \\
\hline
\end{tabular}

Wilcoxon test, Significance value $(\mathrm{p})<0,05$; that means on the two groups have significantly different values.

Table 3: Difference in decrease of plaque index scores of FPD users before and after using $12.5 \%$ VCO mouthwash and aquades for 4 days

\begin{tabular}{llll}
\hline Mouthwash & $\mathbf{n}$ & \multicolumn{1}{|c}{ plaque index score } & p \\
\cline { 3 - 3 } & & Median (minimum-maximum) & \\
\hline $12,5 \%$ VCO & 20 & $1.5(0.5-2)$ & $<0.001$ \\
Aquades & 20 & $0(0-0.5)$ & \\
\hline
\end{tabular}

Mann-Whitney test, Significance value $(\mathrm{p})<0,05$; that means on the two groups have significantly different values.

was not done in this study because subjects had to fulfill certain inclusion criteria. Therefore, consecutive sampling was done, and all subjects who fulfilled inclusion criteria were recruited to participate in the study until the required sample size was met [7]. Randomization was only done during group allocation. Subjects were excluded from this study if they had diabetes mellitus or periodontitis with a pocket depth of $\geq 5 \mathrm{~mm}$, if they consumed antibiotics or smoked, or if they 
Table 4: Difference in decrease of plaque index scores of FDP users before and after using $12.5 \%$ VCO mouthwash between age groups

\begin{tabular}{|c|c|c|c|}
\hline \multirow[t]{2}{*}{ Variable } & \multirow[t]{2}{*}{$\mathbf{n}$} & $\Delta$ plaque index score & \multirow[t]{2}{*}{$\mathbf{p}$} \\
\hline & & Median (minimum-maximum) & \\
\hline \multicolumn{4}{|c|}{ Age (year old) } \\
\hline $18-44$ & 11 & $1.5(1-2)$ & 0.308 \\
\hline $45-64$ & 7 & $1(0.5-1.5)$ & \\
\hline$\geq 65$ & 2 & 1.5 & \\
\hline
\end{tabular}

Kruskal-Wallis test, Significance value $(p)<0,05$; that means on the three groups have significantly different values

Table 5: Difference in decrease of plaque index score of FDP users before and after using $\mathbf{1 2 . 5 \%}$ VCO mouthwash between gender, tooth brushing habits, and restoration margin locations groups

\begin{tabular}{|c|c|c|c|}
\hline \multirow[t]{2}{*}{ Variable } & \multirow[t]{2}{*}{$\mathbf{n}$} & $\Delta$ plaque index score & \multirow[t]{2}{*}{$\mathbf{p}$} \\
\hline & & $\begin{array}{l}\text { Median } \\
\text { (minimum-maximum) }\end{array}$ & \\
\hline \multicolumn{4}{|l|}{ Gender } \\
\hline Male & 5 & $1.5(1-2)$ & \multirow[t]{2}{*}{0.672} \\
\hline Female & 15 & $1.5(0.5-1.5)$ & \\
\hline \multicolumn{4}{|c|}{ Tooth brushing habits } \\
\hline Regularly & 14 & $1.5(1-2)$ & \multirow[t]{2}{*}{0.02} \\
\hline Irregularly & 6 & $1(0.5-1.5)$ & \\
\hline \multicolumn{4}{|c|}{ Restoration margin } \\
\hline \multicolumn{4}{|c|}{ locations } \\
\hline Equigingival & 15 & $1.5(1-2)$ & \multirow[t]{2}{*}{0.004} \\
\hline Subgingival & 5 & $1(0.5-1)$ & \\
\hline
\end{tabular}

Mann-Whitney test, Significance value $(\mathrm{p})<0,05$; that means on the two groups have significantly different values.

used a fixed orthodontics appliance. This was due to the fact that these factors could affect the hygiene and health of patients' periodontium tissue [1].

The mouthwash used in this study was VCO, produced using the centrifugation method, because it has a natural antibacterial content of $48.7 \%$ lauric acid. Lauric acid is a natural antibacterial substance that can kill several microorganisms that have fatty acid containing cell membranes. Streptococcus mutans, the most commonly found bacteria in dental plaque, has cell membranes that contain fatty acids $[3,4]$. The concentration of the VCO is $12.5 \%$. Previous studies on the effect of $12.5 \%, 25 \%$, and $50 \%$ VCO on the growth and protein profile of $S$. mutans have been done. The results showed a decrease in colony counts and a change in the protein profile, but the concentration of VCO did not correlate positively with the antimicrobial effectiveness toward S. mutans $[8,9]$.

Subjects were randomly divided into two groups. The first group consisted of 20 subjects who were given the $12.5 \%$ VCO mouthwash and the second group consisted of 20 subjects who were given aquades. The mouthwash was given in the single-blind method; patients did not know whether they had received $12.5 \%$ VCO mouthwash or aquades. Both mouthwashes were labeled "mouthwash containing $12.5 \%$ VCO." Both mouthwashes were also given in $30 \mathrm{ml}$ bottles. This blinding was done to decrease both bias and the placebo effect; subjects given less potent intervention may do things that will alter the course of their diseases and therefore affect the results of the study [7].

Subjects used the mouthwash for 4 days, according to previous studies that stated there was already a decrease in gingival index scores on bridges after 4 days of using 12.5\% VCO mouthwash [5]. Plaque index scores were measured using the Turesky, Gilmore, and Glickman method or Modification of the Quigley Hein (TQHPI) that uses disclosing solution because this measurement is often used in plaque control measurement [6].

Statistical analysis in Table 2 shows that using $12.5 \%$ VCO mouthwash may cause a decrease in the plaque index scores of FPD users. This is in line with the previous study conducted by Peedikayil et al. in 2015 in India. That study showed that using VCO as mouthwash could significantly decrease plaque and gingival index scores since day 7 [3].

VCO used as mouthwash can decrease plaque and gingival index scores because it can create an oil layer on tooth surfaces, therefore decreasing plaque adhesion and bacterial coaggregation. The lauric acid content of coconut oil can easily react with saliva, which is alkalic, and form lauric sodium, the main content of soap; this accounts for the cleaning action and decrease in plaque accumulation $[3,10,11]$

The lauric acid in VCO is an antibacterial substance that can kill several microorganisms with a fatty acid containing cell membranes, such as Gram-positive and Gram-negative bacteria [3,4]. The study shows that VCO can inhibit the growth of $S$. mutans by degrading the membrane protein. This study was also supported by another study that showed that fatty acid scan kills bacteria through cell membrane disintegration $[4,12]$

A study by MamtaKaushik et al. showed a significant decrease in colony counts of $S$. mutans in saliva after using VCO as a mouthwash for 2 weeks [10]. A study by Peedikayil et al. on children aged 8-12 also showed that VCO is as effective as chlorhexidine in decreasing the number of $S$. mutans in saliva and plaque [11]. However, in this study, the antibacterial effect of $12.5 \%$ CO mouthwash was not observed.

The statistical analysis results in Tables 2 and 3 show that using $12.5 \%$ VCO as a mouthwash is significantly more effective than aquades in decreasing the plaque index scores of FPD users. Aquades in this study were used as a negative control. This result is in accordance with a previous study by Kaushik et al. that compared the effectivity of VCO, chlorhexidine, and aquades in decreasing the colony counts of $S$. mutans. It showed that VCO and chlorhexidine could significantly decrease colony counts of $S$. mutans, while there was no decrease in $S$. mutans colony counts after using aquades [11].

In this study age and gender did not affect the decrease of the plaque index scores of FPD users who used $12.5 \%$ VCO mouthwash. This result is not in accordance with the study by Al-Sinaidi in Saudi Arabia that showed that an abutment tooth in older age groups has a greater plaque index, gingival index, and pocket depth [2]. A study by Indirawati and Lannywati in Jakarta also showed that there was a correlation between age and oral hygiene status, but there was no significant correlation between gender and oral hygiene status [13]. A study by Reitemeier et al. in Germany showed that there was no significant correlation between gender and oral hygiene status. The difference in results could be caused by the disproportional difference in the number of subjects between age and gender groups. Subjects' attention to their oral health and hygiene may also vary between regions

Results of statistical analysis illustrated in Table 5 show that there was a significant difference in decrease in plaque index scores according to the tooth brushing habits of FPD users who used $12.5 \%$ VCO mouthwash. Those who brush their teeth regularly showed a greater decrease in their plaque index score compared to those who brush their teeth irregularly. This shows that regular tooth brushing habits significantly affect the decrease in plaque index scores and $12.5 \%$ VCO mouthwash may be used as additional plaque control.

This is in accordance with a previous study that showed that plaque decrease will correlate positively with tooth brushing time $[14,15]$. 
According to health research in 2013, 98.1\% Jakarta citizens brush their teeth daily, but most of them do it while taking a bath in the morning or afternoon.

The proper tooth brushing habit (after breakfast and before bed) was only found in $3.5 \%$ of Jakarta citizens [16]. Therefore, it is important to promote dental health education for patients and for denture wearers in particular, by teaching them proper tooth brushing habits and doing chemical plaque control with mouthwash as an additional way of maintaining oral hygiene.

Results of statistical analysis illustrated in Table 5 show that there was a significant difference in the decrease in plaque index scores between restoration margin locations in FPD users who used 12.5\% VCO mouthwash. Equigingival margin locations showed a greater decrease in plaque index scores compared to subgingival locations. This is in accordance with a previous study that showed that subgingival restoration margin locations have a higher plaque index and sulcular bleeding index compared to equigingival and supragingival locations $[2,17]$. However, there was no subject with a supragingival restoration margin location in this study.

The result of this study showed that $12.5 \%$ VCO mouthwash is effective in decreasing the plaque indexes of FPD users. This mouthwash is made from plants and is safe to use. The making of this mouthwash also provides another benefit, which is empowering the coconut plantations in Indonesia. VCO has a relatively cheap price, and it is also known to have other potential uses in improving health. It is hoped that this study may be useful for the community and to improve health in general.

The limitations of this study were as follows: The measurement was only done once; there was no subject with a supragingival restoration margin location; and denture surface roughness, abutment tooth regions, and duration of FPD usage were not taken into account.

\section{CONCLUSION}

There was a difference in plaque index scores of FPD users before and after using $12.5 \%$ VCO mouthwash, and there was a difference in decrease in plaque index scores between FPD users who used $12.5 \%$ VCO mouthwash and aquades. There was no difference in decrease in plaque index scores of FPD users before and after using 12.5\% VCO mouthwash between age and gender groups, but there was a difference according to tooth brushing habits and restoration margin locations.

\section{ACKNOWLEDGMENT}

Authors are thanful to the University of Indonesia for the financial and technical support.

\section{REFERENCES}

1. Newman MG, Takei HH, Carranza FA. Clinical Periodontology. $9^{\text {th }}$ ed. Philadelphia: Saunders; 2003.

2. Al-Sinaidi A, Preethanath RS. The effect of fixed partial dentures on periodontal status of abutment teeth. Saudi J Dent Res 2014;5:104-8.

3. Peedikayil FC, Sreenivasan P, Narayanan A. Effect of coconut oil in plaque related gingivitis-A preliminary report. Niger Med J 2015;56:143-7.

4. Silalahi J, Permata YM, Putra ED. Antibacterial activity of hydrolized virgin coconut oil. Asian J Pharm Clin Res 2014;7:90-4.

5. Dewi RS, Nuning F, Oktanauli P, Setiawan R. Effect of $12,5 \%$ VCO (Virgin Coconut Oil) on decreasing gingival index on denture bridge. J Ilmiah Teknologi Kedokt Gigi 2012;9:1-11.

6. Cugini M, Thompson M, Warren PR. Correlations between two plaque indices in assessment of toothbrush effectivene. J Contemp Dent Pract 2006; $7: 1-11$.

7. Sastroasmoro S, Ismael S. Dasar-dasar Metodologi Penelitian Klinis. $4^{\text {th }}$ ed. Jakarta: Sagung Seto; 2011.

8. Kurniani D. Pengaruh Virgin Coconut Oil Metode Sentrifugasi Terhadap Pertumbuhan Dan Profil Protein Streptococcus Mutans Serotipe C Secara In Vitro. Skripsi. Jakarta: Fakultas Kedokteran Gigi Universitas Indonesia; 2007.

9. Hasriati E. Pengaruh Virgin Coconut Oil (VCO) Hasil Fermentasi Terhadap Pertumbuhan dan Profil Protein Streptococcus Mutans Serotipe C Secara In Vitro. Skripsi. Jakarta: Fakultas Kedokteran Gigi Universitas Indonesia; 2007.

10. Kaushik M, Reddy P, Sharma R, Udameshi P, Mehra N, Marwaha A. The effect of coconut oil pulling on Streptococcus mutans Count in saliva in comparison with chlorhexidine mouthwash. J Contemp Dent Pract 2016;17:38-41.

11. Peedikayil FC, Remy V, John S, Chandru TP, Sreenivasan P, Bijapur GA. Comparison of antibacterial efficacy of coconut oil and chlorhexidine on Streptococcus mutans: An in vivo study. J Int Soc Prev Community Dent 2016;6:447-52.

12. Batovska DI, Todorova IT, Tsvetkova IV, Najdenski HM. Antibacterial study of the medium chain fatty acids and their 1-monoglycerides: Individual effects and synergistic relationships. Pol J Microbiol 2009;58:43-7.

13. Tjahja I, Ghani L. Dental and Oral Health Status of Puskesmas DKI Jakarta's Visitors in 2017. Bul Penelitan Kesehatan 2010;38:52-66.

14. George J, John J. The significance of brushing time in removing dental plaque. Int J Dentistry Oral Sci 2016;3:315-7.

15. Creeth JE, Gallagher A, Sowinski J, Bowman J, Barrett K, Lowe S, et al. The effect of brushing time and dentifrice on dental plaque removal in vivo. J Dent Hyg 2009;83:111-6.

16. Badan Penelitian dan Pengembangan Kesehatan Kementerian Kesehatan RI. Riset Kesehatan Dasar 2013. Jakarta: Badan Penelitian dan Pengembangan Kesehatan Kementerian Kesehatan RI; 2013. p. 117.

17. Nayer A, Rayyan M, Osman E, Badr S. An update on the effect of crown margin locations and materials on periodontal health. Egypt Dent J 2011;58:3639-44 